\title{
(息)
}

Citation:

Bratton, J and Gold, J (2015) Towards Critical Human Resource Management Education (CHRME): a sociological imagination approach. Work, Employment and Society, 29 (3). 496 - 507. ISSN 0950-0170 DOI: https://doi.org/10.1177/0950017014545266

Link to Leeds Beckett Repository record:

https://eprints.leedsbeckett.ac.uk/id/eprint/1493/

Document Version:

Article (Accepted Version)

The aim of the Leeds Beckett Repository is to provide open access to our research, as required by funder policies and permitted by publishers and copyright law.

The Leeds Beckett repository holds a wide range of publications, each of which has been checked for copyright and the relevant embargo period has been applied by the Research Services team.

We operate on a standard take-down policy. If you are the author or publisher of an output and you would like it removed from the repository, please contact us and we will investigate on a case-by-case basis.

Each thesis in the repository has been cleared where necessary by the author for third party copyright. If you would like a thesis to be removed from the repository or believe there is an issue with copyright, please contact us on openaccess@leedsbeckett.ac.uk and we will investigate on a case-by-case basis. 
Towards Critical Human Resource Management Education (CHRME): A Sociological Imagination Approach.

\begin{abstract}
In this article, we explore the professional standing of the discipline of human resource management (HRM) in business schools in the post-financial crisis period and, using the prism of the sociological imagination, explain the learning to be gained from teaching HRM that is sensitive to context, power and inequality. The context of crisis provides ideal circumstances for critical reflexivity and for integrating wider societal issues into the HRM curriculum. We argue for Critical Human Resource Management Education or CHRME, which, if adopted, would be an antidote to prescriptive practitioner approaches. We set out five principles for CHRME: using the 'sociological imagination' prism; emphasizing the social nature of the employment relationship; investigating paradox within HRM; designing learning outcomes that encourage students to appraise HRM outcomes critically and reflexive critique. CHRME offers a teaching strategy that does not neglect or marginalize the reality of structural power, inequality and employee work experiences.
\end{abstract}

\title{
Keywords
}

Crisis, employment relationship, critical HRM, pedagogy, sociological imagination 


\section{Towards Critical Human Resource Management Education (CHRME): A Sociological Imagination Approach.}

Since the late 1980s, there has been a proliferation of theory building about the exact nature and significance of HRM. In tandem, the context of HRM education in the UK has undergone monumental changes. These changes include privatization, deregulation, free markets and withdrawal of state intervention in many areas of social provision (Harvey, 2007). Management education cannot be immune from these wider changes, as witnessed by the influence of "the market" in the academic labour process (e.g., Callinicos, 2006). The 2008 Global Financial Crisis and the post-crisis enforced austerity has spawned an argument that business schools are complicit in the crisis by largely failing to act as an intellectual counterweight to the neo-liberalist consensus. Currie et al., (2010:S1) opined, "While we wait to see how the economic crisis unfolds, it is beholden on us to reflect more deeply and critically on the purpose and content of business school education.” In the light of all these diverse debates, our aim is to discuss human resource management (HRM) education in the post-global financial period and to explain the beneficial learning to be gained from teaching HRM that is sensitive to context, power and inequality. The American sociologist, C. Wright Mills, advocated an intellectual practice that understands personal problems by looking 'beyond them'. To be able to articulate the connections between individual experienced 'troubles' and wider social structures is, he argued, 'to possess the sociological imagination' (1959/2000: 11). Although the sociological imagination takes its meaning from a given context, to be understood it has to transform the context in which it is inscribed. Its wider appeal, 
therefore, is the potential for opening up the production of a new context (Latimer and Skeggs, 2011). Using the prism of Mills' sociological imagination, we focus on the idea that to understand HRM 'troubles' we are required to look beyond them, at the social embeddedness of HRM. We call such an approach Critical Human Resource Management Education or CHRME. In our view, such an intellectual practice helps to address recent concerns to make the learning culture in business schools more critical (Delbridge and Keenoy, 2010). As we shall explain, CHRME focuses on the development of a teaching and learning culture that focuses less on the 'what' and 'how' of HRM, but shifts the emphasis towards the 'why' of HRM. That is, with the everyday processes and human actions that occurs in the workplace and their impact on employees being the main focus of study. CHRME adds to a growing body of critical management pedagogy.

We begin by providing a brief overview of the development and critique of contemporary HRM. This is followed by a consideration of the wider contextual factors that determine, or at least are shape, HRM education before proceeding to explore the perceived crisis in HRM. Finally, we outline the need for a shift towards CHRME. In so doing, we recognize that workplaces remain arenas of asymmetrical power relationships, antagonism, and inequality, a reality that is conspicuously absent from conventional wisdoms in HRM education, often reducing the field to mere technical competencies and rhetorical scripts. We will, therefore, offer the thesis that there is beneficial learning to be gained from transforming the teaching of HRM in business schools to one that is contextsensitive, that adopts reflexive pedagogical practices, which encourages a critique of prevailing ideology and ways of acting, and does not neglect or marginalize the reality of 
structural power, inequalities and employee work experiences.

\section{The ascendency and critique of contemporary HRM}

The rise of the HRM paradigm in Britain from the late 1980s is closely linked with another seminal development: the cognitive capture of the political elite by the neoliberal ideology that challenged post-war consensus around Keynesianism and labour collectivism. This ideological impulse saw the renaissance of 'market discipline', the shrinking of the state and a shift of the balance of economic power from labour to capital (Harvey, 2007). The rise of this neo-liberalist agenda provided the backdrop to the change towards individualized employment relations and, in Britain, a burgeoning of academic interest in the study of the U.S. import, HRM. An added fillip was the welldocumented decline of trade union membership, collective bargaining coverage and strikes and the evident eclipse by the once-dominant academic field of industrial relations (Darlington, 2009).

John Storey's (1989) seminal text generated the 'first wave' of debate on the nature and ideological significance of the HRM model. One aspect of the debate focused on 'hard' and 'soft' versions of HRM. The 'hard' version gravitated toward the 'resource' concept to strategically manage work and the employment relationship. It was predicated on orthodox management theory that viewed workers as a cost and therefore must be controlled. The 'soft' HRM model, discussed in Walton's (1985) early and influential paper 'From Control to Commitment in the Workplace' considers employees as assets rather than as a disposable liability. It emphasized the term 'human' and advocated high investment in employees to secure high motivation and the performance benefits of shifting from 'control' to 'commitment' strategies to enlist employee skills 
and loyalty. This socially consensual management model became known by various labels, such as the 'high-commitment workplace' (HCW). A determinate 'bundle' of HRM 'best practices' and 'lean' forms of work organization facilitated the possibilities of synergies, which, it was argued, provided a distinctive basis for sustainable competitive advantage (Barney, 1991). The newly imported HRM paradigm was heavily influenced by the 'strategy' concept (Porter, 1985). This led to the 'second wave' of debate on strategic HRM (SHRM), which posited that to "survive” HRM must be "integrated as a vital part of the planning system in organizations” (Devanna et al., 1984:11). In the 1990s, a 'third wave' of research and publication emerged that focused on the HRMperformance relationship. Designing a combination of determinate HRM practices became the issue in the HRM academic field (Ichniowski et al., 1996). The ensuing HRM-performance debate has been intense and often inconclusive (Gerhart 2008), making the 'performance goals' of the research an "ill-fated project" (Delbridge and Keenoy, 2010: 804). For some academics, the HRM model was a distinctive approach that signalled the beginnings of a new theoretical sophistication, while detractors characterized HRM as "old wine in a new bottle" or "a wolf in sheep's clothing" (Keenoy, 1990).

In Britain, the HRM paradigm came under critical scrutiny from three academic fields: industrial relations (Godard, 1991; Guest, 1987; Hyman, 1987), critical management studies (Keenoy, 1990; Watson, 2004) and labour process theory (Thompson and Ackroyd, 1995). The antecedent of the industrial relations critique of HRM is found in an early contribution from Guest (1987) in which he drew connections between industrial relations and HRM. Employment relations under 'old' style personnel 
management were categorized as pluralist, collectivist and low trust, whereas, in contrast, new HRM regimes were characterized as unitarist, individualist and high trust. HRM was seen as a Trojan horse for union avoidance. Hyman (1987) offered a Marxian analysis arguing that employer commitment to employees is always conditional and both the control over and commitment from workers is the leitmotiv of the HRM model. Historically, there is ample evidence of gender-based occupational segregation with men dominating 'masculine' IR negotiating positions, while 'soft' HR practices, such as recruitment and training, was devolved to women (Legge, 1986). The academic discourse reflected the gendered perceptions of IR and HRM, with an agenda, largely, set by “important men” in one discipline talking to other "important men” in another (Townley, 1994:16). A coterie of critical management studies (CMS) scholars emphasize the need to understand the wider social-economic context that shape - if not determine management action (Delbridge and Keenoy, 2010). Karen Legge (2005) provided a seminal critique of the HRM model, not least for the empirical mismatch between theory and actual HR practices, that has become an iconic description: the 'rhetoric' and 'reality' of HRM. Watson (2004) argued that HRM neglected the "unintended consequences" and the "collateral damage" to others resulting from the application of HRM practices. PostBraverman, Labour Process Theory (LPT) unmasked the crucial role HRM techniques play in organizing and controlling the workforce. One of the key propositions of LPT is the indeterminacy of the employment contract - the mismatch between the capacity for work and actual work effort - and, concomitantly, the persistence of worker resistance to management control strategies attempting to close the gap (Thompson and Ackroyd, 1995). In this view, HRM constitutes a nexus of control practices, or a technology of 
power, that were designed to make workers' behaviour and performance calculable and predictable (Townley, 1994). This summary of critical voices is inherently more sceptical about the 'progressive' nature of HRM and its capacity to reconcile the competing interests of capital and labour. Like HRM, these critical approaches do not speak with one voice, but they have provided a useful antidote to prescriptive, normative approaches to HRM.

\section{The context of management education}

Alongside the import of HRM, the context of management education has undergone monumental changes. These changes include: the increasing dominance of the HRM field at the expense of IR, the imposition of 'market discipline' in university education (Callinicos, 2006; Willmott, 1995) and a growing emphasis in teaching "employability" skills (Yorke, 2006). The eclipse of IR by HRM is illustrated by the closure of Keele University's department of industrial relations. The university's rationale for closure was the claim that individual IR academics did not possess the "appropriate skill sets" to teach HRM. The University's decision, however, was widely interpreted as an "attack on the legitimacy of critical social science” (Darlington, 2009:1). While not to diminish the significance of the closure of the department in Keele, those of us who started our career teaching trade union and IR studies have reached an accommodation with the teaching of HRM by adopting a critical approach derived from the IR tradition. However, individual accommodation does not lessen the significance of the rise of the so-called 'businessfacing' university. With research and teaching priorities designed to meet the needs of business, these new institutions are emblematic of the effects of competitive imperatives 
shaping university curriculum and education.

Less obvious are the complex ways in which academics have become embedded in a nexus of academic procedures and practices, such as budgeting and bidding, and how these invisible technologies of power “estrange” academics (Latimer and Skeggs, 2011: 393). An awareness of the neo-liberal context is an important consideration in the debate on university management education and pedagogy. Not least, because the perceived commodification of education and failure to problematize 'client power' can undermine efforts by teaching faculty to introduce critical management pedagogy (Sinclair, 2007). The Chartered Institute of Personnel and Development (CIPD) has had a direct effect on the university HRM curriculum by emphasizing explicit 'what' and 'how' knowledge, with less attention to its outcomes and the interests it serves (Watson, 2010). The trend towards teaching 'what' and 'how' knowledge and 'competencies' is, in part, driven by the CIPD and by research evincing that most preferred employers report they look to recruit graduates with “employability skills”, defined as “a set of achievements, skills, understandings and personal attributes, that make graduates more likely to gain employment” (Yorke, 2006: 8).

The liberal concept of a university is to act as a centre of free thought where intellectuals can challenge beliefs and be the source of new thinking. Rarely, however, has this concept been realized for long periods. In the 1920s, the French essayist, Julien Benda, argued in The Treason of the Intellectuals (1928) that scholars had abandoned the ideal of "disinterested judgement” and had supported "flagrant injustices” in their own countries. George Davie’s (1986) “democratic intellectualism” resonated with Benda’s 
argument thematically. Today, scholars in business schools are collectively vulnerable to the accusation of intellectual betrayal. Far from acting as a catalyst for critiquing the dominant neoliberal agenda, business schools, generally have offered little intellectual opposition to free-market ideology. There are, of course, exceptional critical scholars in Russell Group and post-1992 university business schools. The central argument of this article is that the majority of management educators have neglected critical social science. The abandonment of the panoply of intellectual ideals has had the effect of legitimizing the neoliberal agenda and, consequently, it can be argued, management scholars are partly to blame for the 2008 crisis (Currie et al., 2010). That business schools largely failed to act as a counterweight to prevailing neo-liberalism ideology is perhaps best illustrated by the pointed observation by American economist, Paul Krugman: “economists have been part of the problem, not part of the solution” (2012: 92). The failure of mainstream economics is further highlighted by recent reports of undergraduates challenging the dominance of orthodox free-market teaching and demanding a more eclectic curriculum that includes, amongst other issues, inequality (Inman, 2014).

The relevance and value of critical social science is illustrated by Gillian Tett's (2009) searing narrative of the global financial crisis. She argues that finance is presented as a string of mathematical equations and that the economic models used by the bankers did not give enough emphasis to all the "human issues". Thus "the finance world's lack of interest in wider matters cuts to the very heart of what has gone wrong” (2009: 298). In essence, politicians, financial regulators and bankers failed to employ what Tett calls "holistic thought”, one that analyzes personal or local problems collectively and, often 
challenges social elites, with full understanding that these problems are linked to wider macro and global structures. We argue here that management scholars palpably failed to employ holistic thinking too.

\section{HRM: a discipline in crisis}

The post-global financial crisis context has cast a long shadow over business schools and HRM education therein. The crisis in the academic management discipline of HRM takes several forms. The first is the discrepancy between the rhetoric and social reality of HRM. In this 'age of austerity', insecure zero-hour contracts, low pay, underemployment, in-work poverty, income inequality and seven-figure bonuses to 'supermanagers' (Piketty, 2014: 315) sits uncomfortably with the widely espoused principle 'people are an asset'. These developments impact negatively on the moral authority of managers, generally, and HRM professionals in particular. The second is the consensual HRM-inspired HCW model. The global financial crisis has highlighted not only the problems of reconciling control-cooperation dynamics but, at both an intellectual and practical level, it raises the perennial question whether global free-market capitalism can deliver on the promises of mutuality (Thompson, 2003). Those organizations that have achieved performance gains through the appropriate HRM practices are "not immune from destructive effects of enhanced demand for shareholder value” (Thompson and Harley, 2008: 161).

A third consideration is the status of academic HRM. It is evident that its internal coherence has again become problematic. As an intellectual construct, "carved out of the general managerial function” (Kaufman, 2008: 34), HRM-performance research provides compelling evidence that the boundaries and subject matter of HRM need to be redefined. 
Thus, research that conceptualizes the HR 'black box' as a relational construct suggests that, as an academic discipline, HRM has to be defined in a more broad, generic way to include, for example, theories of leadership, organizational culture and organizational behaviour. By implication, this would justify bolting the academic discipline of HRM back onto the general management function. Individual scholars with a background in research and teaching in HRM would find themselves vulnerable to redundancy because they have an inappropriate skill set to teach general management: a case of déjà vu.

Post-2008 developments have put an unforgiving spotlight on economics teaching in Britain's universities (Inman, 2013; 2014). A similar dynamic could operate in management teaching. Like their peers studying economics, if management students perceive that the prescriptive HRM 'toolbox' approach bears little relation to the way organizations function, HRM teaching will come under pressure to embrace inequality theories and alternative governance models to undermine the dominance of orthodox management theories. There is now a body of work (e.g. Alvesson et al, 2009; Delbridge and Keenoy, 2010; Thompson, 2003; Watson, 2010) that acknowledges the need for critical management pedagogy. Specifically, it is argued that if business schools are to contribute to finding solutions to a variety of crises they have to engage their students in a type of learning that will produce leaders who are able to make organizations effective in a variety of different ways: more efficient, more ecologically sustainable, more satisfying, more equitable and more democratic.

Reynolds (1999) enunciates four broad principles of critical management pedagogy: questioning the taken-for-granted assumptions in the theory and practice of management; making explicit power relations in management practices; challenging 
claims of rationality and objectivity; and movement towards an emancipatory or democratic ideal. Sinclair’s (2007) approach to critical leadership pedagogy emphasizes the need to challenge leadership orthodoxy and to expose management students to critical ideas of power. Although transformative and original in terms of the business school debate, critical HRM education (CHRME) is derivative from the wider debate on critical management studies. The motif of CHRME is to stretch the discipline boundary beyond the concerns of HRM-performance issues and to use the "sociological imagination" to critically explore HRM and business and the relationships between business and society.

\section{Towards CHRME}

For HRM educators, we do present an alternative to current mainstream approaches to teaching HRM in universities, consisting of five principles of CHRME:

Principle 1: The Sociological Imagination - Our approach is principally framed by the sociological traditions around the concept of the "sociological imagination" and social justice. In order to follow Mills' intellectual practice, HRM pedagogy should connect workplace problems to larger macro and global social structures. The value of this approach may be illustrated by two examples. First, the contentious issue of the widening gap between CEO remuneration and median pay for employees needs to be linked to the wider public issue of social justice (Wilkinson and Pickett, 2010). The International Labour Organization (ILO) provides a plethora of statistical information that can be used to demonstrate to students the growth of income inequality. The second example is individual narratives of female graduates who failed to be selected or promoted for professional development (Scurry and Blenkinsopp, 2011) needs to be linked to the 
tenacity of male-dominated hierarchies that act in ways that preserve male privileges and advantages (Wajcman, 1998). These acknowledgements of social reality serve as a reminder that class power and gender still matter. CHRME engenders a more holistic approach and help students to understand that 'selfhoods' are not universal but shaped by life experiences forged by class, gender and race.

Principle 2: Emphasize the social nature of the employment relationship. - At its most basic, the employment relationship embraces an economic relationship: the 'exchange of pay for work’ (Brown, 1988) and that many of the local problems, such as those referred to above, are tied to the contested nature of this exchange and continuing disconnections as a result of instabilities in global capitalism. The 'pay-effort bargain' is continuously relevant for understanding how far the relationship is structurally conflictual because 'effort' it is inherently indeterminate. HRM practices are designed to narrow the divide between potential and actual performance or, in Townley’s (1994: 14) words: "to render individuals and their behaviour predictable and calculable.” The second principle resonates with Hyman's (1975) well-established thesis that the employment relationship should be examined within its broader 'capitalist totality'

Principle 3: Investigate paradox within HRM - A critical HRM pedagogy draws attention to how various paradoxes in HRM are produced and reproduced, in order to encourage a greater understanding of and sensitivity towards managing the employment relationship. Drawing upon the classical work of Weber (1922/1968), detractors (Legge, 2005) have used the 'paradox of consequence' to encourage their audience to view the reality of HRM differently. One example will suffice to illustrate the concept. New work designs were promoted to revitalize organizations in order to enlist 
workers' knowledge and commitment yet what emerged was work intensification with negative effects on employee trust. As Thompson (2003:371) rightly observed, while progressive HRM scholars note the problem of paradox, the forces that undermine the rhetorical homily 'people are our most important asset', and the employers' side of any bargain, are not integral to their analyses.

\section{Principle 4: Encourage students to appraise HRM outcomes critically -}

Rather than designing the syllabus solely around 'performance' orientated priorities, there needs to be a more transparent shift towards questions such as, 'who benefits from HRM practices?', 'what are the purposes to which HRM is put?' and 'what impact do 'better’ HRM practices have on social justice ideals?'. Teaching HRM critically means addressing the 'what', the 'why', and the 'how' of HRM but also examining the effect of HRM practices on employees and society at large. The CHRME approach builds upon the critical employment relations tradition of exploring the processes that regulate the employment contract, and the interconnections between power relations and the socioeconomic context which worker and employer representatives interact. CHRME has to treat the new social contract of balancing profit, people and planet' (3Ps) as problematic. CHRME's context-sensitive approach to teaching and learning means that critical theory "emerges" from students' reflective learning, rather than taught in 'up-front' lecturefocused concentrations (Grey, 2002: 508). Students need be critical thinkers. While we accept that the notion of criticality is informed by many intellectual traditions, there is a consensus on the need to critique rhetoric, tradition, authority, knowledge (Mingers, 2000) and bias and prejudice in decision-making (Antonacopoulou, 2010). 
Principle 5: Adopt the process of reflexive critique - In the era of late modernity, Giddens (1991:5) posits that the 'reflexive project' of the self, consists in sustaining a coherent, yet continuously revised, biographical narrative, which takes place in a context of the dialectical interplay of the local and the global. The relevance of the reflexivity concept is that it raises the vexed question of how critical HRM can be made meaningful and accepted by learners. Antonacopoulou (2010) argues that 'reflexive critique' encourages a critique of prevailing theories, dominant assumptions and existing ways of meaning and propositions (p. 9). CHRME makes use of an empirical-based praxis through the use of learners' life experiences - issues of power, control, inequality - thereby avoiding a sole reliance on sanitized representations of corporate HR. Underpinning CHRME therefore is the application of reflexive critique to explain the dynamics and tensions in the employment relationship. Through the use of empiricalbased praxis, HRM students must learn to look outwards in order to connect personal and workplace problems to larger macro and global social structures, but must also consider how their understandings of reality are subjective, forming the assumptions and values from which actions are taken (Cunliffe, 2004).

Michael Collins (1991) contends that transformative pedagogy "needs to be informed by a theory of justice and social theories of action with which its practitioners can engage” (p. 118). Re-interpreting Collins' thesis, we argue that a CHRME is a potential transformative force in that it sees the main task for workplace scholars is to challenge all taken-for-granted assumptions about management practices, to ask hardhitting questions on power and inequality and to encourage critical reflection on employment issues and their place within both their societal and global contexts. Further, 
from the view of a transformative pedagogy, CHRME privileges a concern with influencing HR policy and practice, on the one hand, and purposively seeking ways to create a more equitable, dignified and sustainable workplace on the other. If these shared commitments coalesce, CHRME would evade complicity with prevailing forms of mismanagement, social injustice and environmental degradation.

\section{Conclusions}

The global financial crisis and, especially in Britain, the enduring focus on maximizing short-term profits and share price by ‘ownerless corporations’ (Hutton, 2014) provides a cogent case for critically examining management education. Within this contextual framework, it seems clear that university management education has to obsess less on 'employability' and focus on studying the hidden moral assumptions of management theory, the efficient distribution of wealth and exploring how management choices affects workers, society and the environment. Academic HRM has a responsibility to educate a new generation who can better address the competing demands for profit, social justice and environmental protection. Related to this responsibility, CHRME plays a pivotal role in unmasking a world of structural inequalities, indeterminacy, indignities, and often tyranny: workplace life as it is. Paraphrasing Julien Benda (1928) and philosopher George Davie (1986), the main task for HRM education intellectuals is to offer social leadership and to try to be attuned to the realities of domination, exploitation and discrimination. CHRME is a contribution to a wider debate in university education on the tradition of critical social science (Elger, 2009; Watson, 2009; 2010) and the need to make management education more 'critical' (Currie et al., 2010). Since 1989, the voluminous literature on HRM affirms a process of 'maturity' of a 
discipline that looks 'outwards' to different societal effects and 'inwards' to cause-effect issues (Boxall et al., 2007). The enhanced status these developments have given to the discipline should not be under-estimated. However, the CHRME impulse we advocate puts the onus on management educators to make the academic field of HRM less partisan and more critical by using a systematic set of principles to extend the analysis of HRM to largely excluded voices and a greater concern with questions of 'by whom' and 'for whom?' Further, CHRME, by broadening the scope of the subject beyond workplacelevel analysis, connects analytical HRM, employment relations, the labour process and critical management traditions. Alongside CMS, LPT and IR traditions, CHRME principles can contribute towards unmasking the reality of structural inequalities in workplace life. Anything less is to falsify and impoverish the notion of critical social science in the academic field of HRM and management generally.

The focus of this article has been on critical pedagogy and, in the context of 'disconnected' global capitalism, much has been omitted due to space. Thomas Piketty's Capital in the Twenty-First Century has effectively punctured the myths of neo-liberal economic agenda and made a compelling case for resurrecting the state (2014: 476) to address the present crisis in inequality. We take from this work that state labour market policies and union strategies are integral to CHRME. We are also aware that given the commodification of HE, it is easier to research and publish critically than it is to teach critically, and we need to know whether the effects of the 2008 global economic crisis has changed what is taught in UK business schools. For example, has the crisis produced HRM modules that challenge mainstream thinking similar to Manchester University's 'Bubbles, Panics and Crashes’ economics module? Finally, further research needs to 
consider the potential and limits of alternative industrial democracy models. To take one example, the Common Weal agenda of the Jimmy Reid Foundation (Duffy et al., 2013) could be subject to robust conceptual and empirical examination. CHRME is a contribution to thinking about the pedagogical tools for exploring such issues.

\section{References}

Alvesson, M., Bridgman, T., \& Willmott, H. (Eds.) (2009). The Oxford handbook of critical management studies, Oxford, UK: Oxford University Press.

Antonacopoulou E.P. (2010) Making the business school more 'critical': reflexive critique based on phronesis as a foundation for impact. British Journal of Management 21, S6-S25.

Barney J.B. (1991) Firm resources and sustained competitive advantage. Journal of Management, 17(1): 99-120.

Benda J (1928/2006) The Treason of the Intellectuals, translated by Richard Aldington London: Norton

Boxall, P., Purcell, J., and Wright, P. (2007) Human Resource Management: Scope, Analysis, and Significance. In P. Boxall, J. Purcell and P. Wright (eds.) The Oxford Handbook of Human Resource Management (pp. 1-16), Oxford: Oxford University Press.

Brown R (1988) The employment relationship in sociological theory. In: Gallie D (ed.) Employment in Britain Oxford, UK: Blackwell, 33-66.

Callinicos A. (2006) Universities In A Neoliberal World. London, UK: Bookmarks.

Collins M (1991) Adult Education As Vocation London, UK: Routledge.

Cunliffe AL (2004) On becoming a critically reflexive practitioner. Journal of Management Education 28(4): 407-426.

Currie G, Knights D and Starkey K (2010) Introduction: a post-crisis critical reflection on business schools. British Journal of Management, 21: 1-5.

Davie GE (1986) The Crisis of the Democratic Intellect Edinburgh: Polygon. 
Darlington R (ed.) (2009) What's the Point of Industrial Relations? In Defence of Critical Social Science. Manchester: British Universities Industrial Relations Association.

Delbridge R and Keenoy T (2010) Beyond managerialism? The International Journal of Human Resource Management 21 (6): 799-817.

Devanna, M.A., Fombrun, C.J. and Tichy, N.M. (1984) A framework for strategic human resource management. In C.J. Fombrun, N.M. Tichy and M.A. Devanna (eds.) Strategic Human Resource Management (pp. 3-18). New York: John Wiley \& Sons.

Duffy, J., Gall, G., and mather, J. (2013) Working Together: A vision for industrial democracy in a Common Weal economy, Glasgow: Jimmy Reid Foundation.

Elger T (2009) Industrial relations and the sociological imagination. In: Darlington $\mathrm{R}$ (ed.) What's The Point Of Industrial Relations? Manchester, UK: British Universities Industrial Relations Association, 96-104.

Gerhart B (2008) Modelling HRM and performance linkages. In Boxall P, Purcell J and Wright P (eds.) The Oxford Handbook of Human Resource Management Oxford: Oxford University Press, 552-580.

Giddens, A, (1991) Modernity and Self-Identity, Cambridge: Polity Press.

Godard J (1991) The progressive HRM paradigm: a theoretical and empirical reexamination. Relations Industrielles/Industrial Relations 46(2): 378-99.

Grey, C. (2002). We are all managers now'; 'we always were': on the development and demise of management. Journal of Management Studies, 36(5), 561-585.

Guest, D. E. (1987) Human resource management and industrial relations. Journal of Management Studies, 24(5): 503-21.

Harvey D (2007) A Brief History Of Neo-liberalism. Oxford, UK: Oxford University Press.

Hutton, W. (2014) It's easy to moan about bonuses, but just how do we fix banks?, The Observer, April 27:42.

Hyman R (1975) Industrial Relations: A Marxist Introduction. Basingstoke, UK: Macmillan.

Hyman, R. (1987) Trade unions and the law: papering over the cracks? Capital and Class, (31): 43-63. 
Ichniowski C, Kochan T, Levine D, Olson C and Strauss G (1996) What works at work: overview and assessment. Industrial Relations, 35(3): 299-333.

Inman P (2013) Economics lecturers accused of clinging to pre-crash fallacies, The Guardian November 11: 21.

Inman P (2014) Economics students' anger over scrapping of module, The Guardian April 04: 29.

Kaufman, B.E. (2008) The Development of HRM in Historical and International Perspective, . In: Boxall P, Purcell J and Wright P (eds.) The Oxford Handbook of Human Resource Management Oxford: Oxford University Press, 19-47.

Keenoy, T. (1990). Human Resource Management: Rhetoric, Reality and Contradiction, International Journal of Human Resource Management, 3 (1): 363-84.

Krugman P (2012) End This Depression Now! (2 ${ }^{\text {nd }}$, Ed.) New York: Norton.

Latimer J and Skeggs B (2011) The politics of imagination: keeping open and critical, The Sociological Review, 59 (3): 393-410.

Legge, K. (1986) Women in Personnel Management, in A. Spencer and D. Podmore (eds.), A Man's World. London: Tavistock.

Legge K (2005) Human Resource Management: Rhetorics And Realities (Anniversary Edition) Basingstoke, UK: Palgrave Macmillan.

Mills CW (1959/2000) The Sociological Imagination (Fortieth Anniversary Edition). New York, NY: Oxford University Press.

Mingers, J (2000) What is it to be critical? Teaching a critical approach to management undergraduates. Management Learning, 31(2): 219-37.

Piketty, T. (2014) Capital in the Twenty-First Century, Translated by Arthur Goldhammer, Cambridge, MASS: Harvard University Press.

Porter, M. (1980) Competitive Strategy. New York: Free Press.

Reynolds M (1999) Grasping the nettle: possibilities and pitfalls of a critical management pedagogy. British Journal of Management, 10(2), 171-84.

Scurry T and Blenkinsopp J (2011) Under-employment among recent graduates: a review of the literature. Personnel Review 40(5): 643 - 659.

Sinclair A (2007) Teaching leadership critically to MBAs: experiences from heaven and hell. Management Learning 38(4): 461-475. 
Storey J (ed.) (1989) New Perspectives On Human Resource Management London, UK: Routledge.

Tett G (2009) Fool's Gold: How Unrestrained Greed Corrupted A Dream, Shattered Global Markets And Unleashed A Catastrophe London, UK: Little Brown.

Thompson P and Ackroyd S (1995) All Quiet on the Workplace Front? Sociology, 29 (4): 19-33.

Thompson P (2003) Disconnected capitalism: or why employers can't keep their side of the bargain. Work, Employment and Society, 17(2): 359-378.

Thompson P and Harley B (2008) HRM and the worker: labour process perspectives. In: Boxall P, Purcell J and Wright P (eds.) The Oxford Handbook of Human Resource Management Oxford: Oxford University Press, 147-165.

Townley B (1994) Reframing Human Resource Management London, UK: Sage.

Walton R (1985) From control to commitment in the workplace. Harvard Business Review, March/ April: 77-84.

Watson T (2004) HRM and critical social sciences. Journal of Management Studies 41(3): 447-67.

Watson (2009) Work and the sociological imagination. Sociology 43(5): 861-877.

Watson T (2010), Critical social science, pragmatism and the realities of HRM. The International Journal of Human Resource Management Studies 21(6): 915-931.

Weber M (1922/1968) Economy and Society. New York, NY: Bedminster.

Wilkinson, R. and K. Pickett (2010). The Spirit Level. London: Penguin.

Willmott $\mathrm{H}$ (1995) Managing the academics: commodification and control in the development of university education in the UK. Human Relations 48: 993-1027.

Wajcman J (1998) Managing Like a Man: Women and Men in Corporate Management North Drive, PA: Pennsylvania State University Press.

Yorke M (2006) Employability in Higher Education: What It Is - What It Is Not, Heslington, York: The Higher Education Academy. 
Towards Critical Human Resource Management 22 